\title{
The effect of anti-hypertensive drugs on the obstructive pancreatitis in rats ${ }^{1}$
}

\author{
Efeitos de fármacos anti-hipertensivos sobre pancreatite obstrutiva em ratos
}

\author{
Roberto de Barros Silva', Fernando Silva Ramalho"I, Leandra Z. Naira RamalhoIII \\ ${ }^{\text {I }}$ Fellow Master degree, Post-graduate Program in Experimental Pathology, Department of Pathology and Forensis Medicine, Faculty Medicine of \\ Ribeirao Preto, USP, Sao Paulo, Brazil. \\ ${ }^{\text {II }}$ PhD Professor, Post-graduate Program in Experimental Pathology, Department of Pathology and Forensis Medicine, Faculty Medicine of Ribeirao \\ Preto, USP, Sao Paulo, Brazil. \\ III PhD Professor and Coordinator of the Post-Graduate Program in Experimental Pathology, Department of Pathology and Forensis Medicine, Faculty \\ Medicine of Ribeirao Preto, USP, Sao Paulo, Brazil.
}

\begin{abstract}
Purpose: To investigate the effect of ACE inhibitor, lisinopril and AT1 blocker, losartan, on the obstructive pancreatitis in rat. Methods: Acute pancreatitis in rats $(n=21)$ was induced for a common hepatic duct were ligated proximal to its entry into the pancreas and the common bile - pancreatic duct were also ligated near its junction with the duodenum, under ether anesthesia, after which the abdomen were closed. The animals was divided in tree groups, being two treated and control group. The animals was treated with Losartan and Lisinopril at the dose of $10 \mu \mathrm{g} / \mathrm{Kg}$ body weight per day, i.p., in a proportional volume, for five days, before and after treatement. Results: The inflammation, collagen deposition in the pancreas of treated animals were smaller, suggesting that the use of antihypertensive agents interfered positively in the depletion of the injury of the pancreas. Scythe showed a correlation between activity of pancreatic stellate cells (PSCs) lower in treated animals when compared to control. Conclusion: The pancreatic stellate cells strength are involved in collagen production during acute pancreatitis and why antihypertensive drugs such as lisinopril and losartan may possibly have beneficial effects in reducing pancreatic fibrosis in models of experimental obstructive pancreatitis.
\end{abstract}

Key words: Pancreatitis. Receptors, Angiotensin. Antihypertensive Agents. Rats.

\section{RESUMO}

Objetivo: Investigar o efeito de um inibidor da ECA, lisinopril e bloqueador AT1, losartan, a pancreatite obstrutiva em ratos. Métodos: Pancreatite aguda em ratos $(\mathrm{n}=21)$ foi induzida por um ducto hepático comum foram ligados proximal à sua entrada no pâncreas e da bílis comum - ducto pancreático também foram ligados perto de sua junção com o duodeno, sob anestesia com éter, após o que abdome foram fechadas. Os animais foram divididos em três grupos, sendo dois tratados eo grupo controle. Os animais foram tratados com lisinopril e losartan na dose de $10 \mu \mathrm{g} / \mathrm{Kg}$ de peso corporal por dia, IP, em um volume proporcional, por cinco dias, antes e depois do tratamento com. Resultados: A inflamação, deposição de colágeno no pâncreas de animais tratados foram menores, sugerindo que o uso de agentes anti-hipertensivos interferiram positivamente na diminuição da lesão do pâncreas. Este estudo mostrou uma correlação entre a atividade das células pancreáticas estreladas (CSP) menor nos animais tratados quando comparados ao control.Conclusão: A força das células pancreáticas estreladas está envolvida na produção de colágeno durante a pancreatite aguda e por medicamentos anti-hipertensivos, tais como lisinopril e losartan pode eventualmente ter efeitos benéficos na redução da fibrose do pâncreas em modelos experimentais de pancreatite obstrutiva.

Descritores: Pancreatite. Receptores de Angiotensina. Anti-Hipertensivos. Ratos.

${ }^{1}$ Research performed at the Pathology Molecular Laboratory and Post-graduation Program, Department of Pathology and Forensis Medicine, Faculty Medicine of Ribeirao Preto, Sao Paulo University (USP), Brazil.

\section{Introduction}

Acute pancreatitis is a severe human disease characterized by acinar cell necrosis, extensive interstitial edema and migration of neutrophils into the damaged gland ${ }^{1}$. The etiology of acute pancreatitis has been considered to be multifactorial, although difference in the triggering mechanisms end up with the same common pathway ${ }^{2}$. The current knowledge shows that the activation of digestive zymogens inside the acinar cells leads to acinar cell injury ${ }^{3}$. Through the autodigestion of pancreatic tissue by the premature activation of proenzymes prior to their release into the duodenum ${ }^{4}$. Some of the crucial factors may include activation of proteolytic enzymes, lipase, kinins and others vasoactives peptides such as angiotensin $\mathrm{II}^{1,5}$. Recent investigations suggested that the ultimate severity of pancreatitis was determined by events that occurred subsequently to acinar cell 
injury, including inflammatory cell recruitment and the release of cytokines and other chemotactic mediators of inflammation ${ }^{6}$.

Renin-angiotensin system (RAS) has been identified to participate in inflammatory events. The local increase in vascular permeability and recrutament of inflammatory cells to the site of injury by the action of inflammatory cytokines is a critical step in the progression of inflammation ${ }^{7}$. The effect of angiotesin II stimulating the synthesis and secretion of vascular permeability factor, synthesis of adhesion molecules and chemokines as well as the migration and adhesion of monocytes and leukocytes ${ }^{8}$ has been demonstraded. The angiotensin II and AT1 and AT2 receptors have been localized in the microcirculation and epithelium of the ductal system in rodent and human pancreas ${ }^{9}$.

Some pancreatic cells have recently been identified, isolated and termed pancreatic stellate cells (PSCs) once they exhibit morphological and functional features similar to cultured hepatic stellate cells ${ }^{10,11}$. PSCs are activated in both experimental and human pancreatic fibrosis by RAS and are the main cellular source of collagen in chronic pancreatitis. Other studies suggest that PSCs play an important role in pancreatic fibrogenesis ${ }^{5}$.

The PSCs are involved in the pathogenesis of chronic pancreatitis, they even can be considered to be therapeutic targets for the suppression of acute pancreatitis. On the other hand, biliar obstruction is the main cause of human pancreatitis and this model could be easily reproduced in rats by the ligature of the bilio pancreatic duct.

Anti -hypertensive drugs have been accepted beneficial effects on acute and chronic pancreatitis ${ }^{12}$. Therefore, the purpose of the present study is to investigate the effect of ACE inhibitor, lisinopril and AT1 blocker, losartan, on the obstructive pancreatitis in rat.

\section{Methods}

The study was previously approved by the Ethics Committee for Animal Research of the Faculty Medicine of Ribeirao Preto - University of Sao Paulo. Male Wistar rats had been housed in a temperature-controlled room with 12-h light-dark cycle and received standard laboratory chow (Purina) and water ad libitum. All animals had been treated according to the International Guiding Principles for Biomedical Research Involving Animals. The body weight of the animals was $200 \pm 15 \mathrm{~g}$ at the time of surgery. Rats were allocated to one of three groups. In the first group $(n=7)$ the animals were treated daily with saline solution, intraperitoneally (i.p.), for five days. Then the common hepatic duct were ligated proximal to its entry into the pancreas and the common bile - pancreatic duct were also ligated near its junction with the duodenum, under ether anesthesia, after which the abdomen were closed ${ }^{13}$. After that the animals received saline solution, i.p., daily, for more five days, Control Group (CG). The second group $(n=7)$ were treated daily with losartan (Merk, Sharp \& Dohme, Rahway, NJ, U.S.A) at the dose of $10 \mu \mathrm{g} / \mathrm{Kg}$ body weight per day, i.p., in a proportional volume, for five days. These animals were subjected to the same surgical procedure and treated with losartan, Losartan Group (LOG), i.p., for more five days. The third group $(n=7)$ were treated daily with lisinopril (Merk, Sharp \& Dohme, Rahway, NJ, U.S.A) at the dose of $10 \mu \mathrm{g} / \mathrm{Kg}$ body weight per day i.p., in a proportional volume, for five days. These animals were subjected to the same surgical procedure and treated with lisinopril, Lisinopril Group (LIG), i.p., for more five days. Then, the animals of all the groups were sacrificed under ether anesthesia.

\section{Histological studies}

Paraffin sections of rat pancreatic tissue were stained by hematoxylin and eosin and for collagen using Sirius - Red ${ }^{14}$. Immunohistochemistry was performed for $\alpha$-smooth muscle actin $(\alpha-$ SMA) and glial fibrillary acidic protein (GFAP).

The different pancreatic stellate cell populations will be evaluated by immunohistochemical staining method (GFAP or $\alpha$-SMA). All tissue samples will be routinely fixed in $4 \%$ neutral formalin and embedded in paraffin. Briefly, $3 \mu \mathrm{m}$-thick sections will be cut from paraffin blocks containing representative pancreatic samples. Paraffin sections will be dewaxed in xylene, rehydrated through a series of graded alcohols, placed in $10 \mathrm{mM}$ citrate buffer and submitted to heat retrieval using a vapor lock for 40 minutes. After heating, the slides will be allowed to cool to room temperature and will be briefly washed with tris-buffered saline. Endogenous peroxidase activity will be blocked with $3 \%$ hydrogen peroxide in methanol for 5 minutes. Normal serum (Universal Quick Kit, Novocastra, Newcastle Upon Tyne, United Kingdom) will be used for 20 minutes to block nonspecific immunoassaying.

Immunohistochemical staining will be performed using a streptavidin-biotin peroxidase system (Novocastra Universal Quick Kit). The following primary antibodies will be incubated for 2 hours at room temperature: smooth muscle actin ( $\alpha$-SMA, 1:100, Dako, Glostrup, Denmark) or glial fibrilary protein (GFAP, 1:100, Dako, Glostrup, Denmark). Following washes in phosphatebuffered saline, biotinylated universal secondary antibody (Novocastra, Universal Quick Kit) will be applied for 15 minutes. The sections will be incubated with the streptavidin -biotin complex reagent (Novocastra, Universal, Quick Kit) for 10 minutes and developed with 3-amino-9-ethyl carbazole (Vector Laboratories, Burlingame, CA, U.S.A) for 15 minutes. The sections will be counterstained with Mayer hematoxylin for 1 minute and mounted with Leucognost (Aquatex, Merck, USA). Positive and negative controls were development. The slides will be evaluated blindly. GFAP and $\alpha$-SMA positive cells, or collagen staining will be counted in serial immunostained or Siriusred sections using a point-counting procedure at a magnification of $x 400$. In the GFAP or $\alpha$-SMA immunostained or Siriusred set of sections, a total of 3000 points per pancreas will be counted for each animal; each point will be classified as GFAP or $\alpha$-SMA reactive cells, or collagen staining ${ }^{14}$.

\section{Statistical analysis}

The results will be expressed as median and range. The data were first compared by Kruskal-Wallis oneway analysis of variance, with the level of significance set at $p<0.05$. The Dunn method will be used to compare all groups. The statistical analysis will be performed with the GraphPad Prism software (GraphPad Software Inc., San Diego, CA, U.S.A). 


\section{Results}

\section{Histopatology}

All 21 animals in the control group or did not develop acute pancreatitis. However the control group had more inflammatory cells and a significant increase of fibrosis $(p<0.05)$, as seen in the business of hematoxylin and eosin and Sirius red (Figure 1A and 1B).

\section{Immunohistochemistry for Stellate Cell Markers}

The $\alpha$-SMA has been shown to be an excellent marker for the activated PSC phenotype in vitro. In this study animals treated, had a lower activity of stellate cells (Figure 1C), when compared with the control group (Figure 1D and 1E) $(p<0.05)$, analyzed by Immunohistochemical staining method (GFAP or $\alpha$-SMA). All these results were measured (Figure 2).
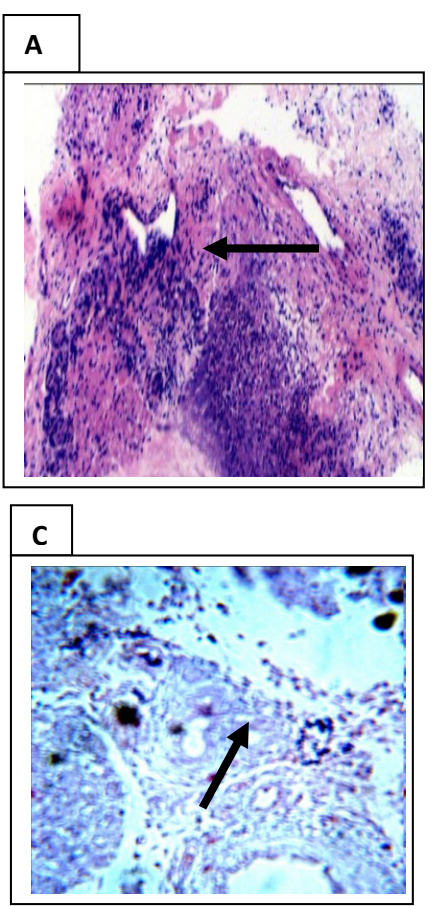
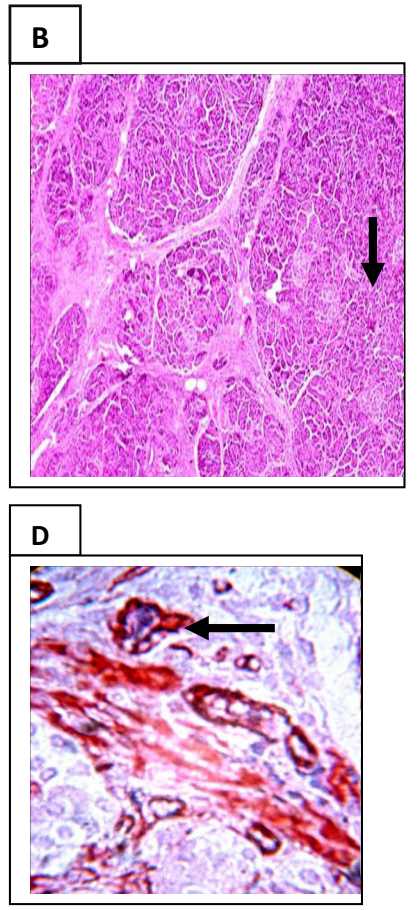

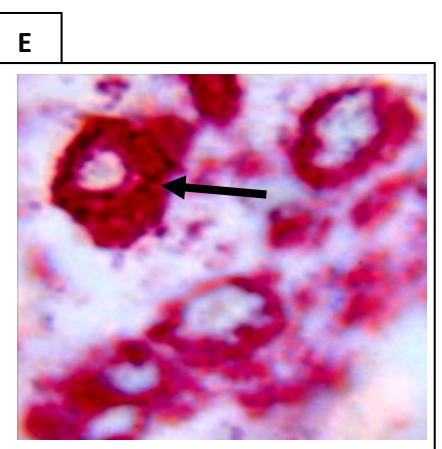

FIGURA 1 - Slides stained by hematoxylin and eosin (A) to inflammatory analysis have showed more neutrophylic inflammatory infiltrate in sample of control group measured in [purple]. Moreover slides stained by Sirius red (B) have showed more collagen deposit in the animals of control group too showed in [eosinofilic]. In the group treated $(\mathbf{C})$ and stained by immunohistochemical staining method (GFAP or $\alpha$-SMA) have less PSCs activated marked in [blue] compared with animals control (D and E) which have more PSCs activated measured in [red] $(p<0.05)$

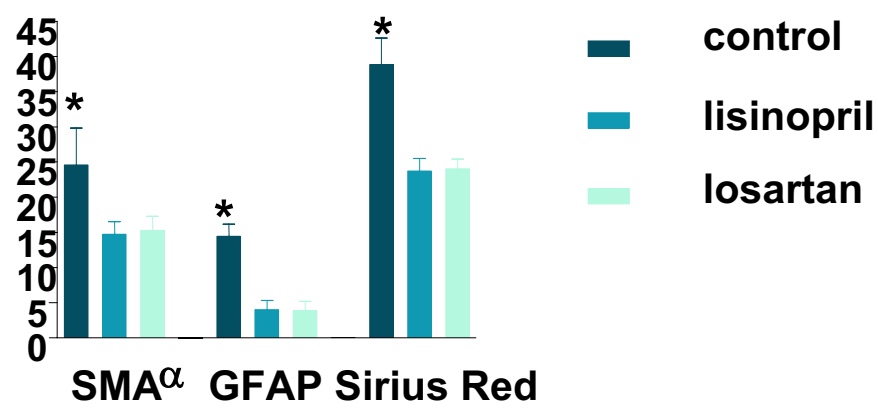

FIGURE 2 - Comparison of the number of pancreatic stellate cells marked for alpha-smooth muscle actin ( $\alpha$-SMA) and fibrillary acidic protein glial (GFAP), and the percentage of points scored by used. The (PS), between the pancreas of control rats treated with lisinopril and losartan. The bars represent the mean $\pm \mathrm{SD}$. ${ }^{*} \mathrm{P}<0.001$, compared to the treaties.

\section{Discussion}

Classicaly, the rennin-angiotensin system (RAS) has been considered a hormonal circulating system. The so-called systemic or circulating RAS plays a crucial role in the maintenance of blood pressure ${ }^{15}$ and electrolyte as well as fuid homeostasis ${ }^{15}$. This is mediated through its constrictive actions on vascular smooth muscle and by its influence on aldosterone secretion from the adrenal cortex, electrolyte transport in kidney, and on thirst as well as sodium appetite in the brain. In addition to its actions on the cardiovascular, renal, and nervous system, the expression of local RAS components in tissues such as the brain, kidneys, adrenals and gonads has led to the proposition that these components may either potentate systemic functions, or have entirely separate activities meeting the specific needs of these individual tissues. There is accumulating evidence that changes in tissue/organspecific RAS may be associated with the pathophysiology of the respective tissue/organ functions ${ }^{15}$.

The physiologically active endocrine product of the circulating RAS, angiotensin II, is spliced from its liver-derived precursor angiotensinogen by a sequential action of two critical enzymes. The first enzyme, rennin, is secreted from juxtaglomerular cells in the kidney ${ }^{1}$.

Renin splits a specific leucine-leucine peptide bond in circulating angiotensinogen, resulting in the formation of the decapeptide angiotensin I. Angiotensin I is then carried via the blood to the lungs, where the second enzyme, ACE, removes two amino acids from the carboxy terminus of angiontensin Ito form the active octapeptide angiotensin II. ACE is a membrane bound enzyme anchored on the endothelium of many vascular beds with the highest concentrations found on the vascular epithelium of the lung ${ }^{10}$. Other enzymes may act on angiotensin I or angiotensin II to yield various active peptide fragments including angiotensin III and angiotensin IV ${ }^{15}$.

The final goal of the RAS is the angiotensin II production that acts through the interaction with two pharmacologically defined receptor subtypes, namely type 1 (At1) and type 2 (At2) that are distributed in numerous target tissues and organs ${ }^{14}$ like pancreas.

The regulation of tissue RAS is subject to a number of factors such hormones, ions and stress. Hypoxic stress is known 
to be one such factor which may lead to changes of tissues RAS expression in, for example, the kidney ${ }^{1}$, the lung ${ }^{10}$, the carotid body, the epididymis and the heart ${ }^{15}$. Chronic hypoxia elicited a marked increase in mRNA and protein expression on angiotensinogen ${ }^{12}$. It has previously been reported that hypoxia could result in the decrease of regional blood flow to several tissues including the pancreas, which may enhance tissue inflammation and injury ${ }^{14}$.

Beside the pancreatic angiotensinogen, there are also measured expression changes by acute pancreatitis of the At1 and At 2 receptors. For At1 receptor, experimental pancreatitis caused a differential mRNA expression for At1a and At1b receptor subtypes such that At1a subtype was unregulated while At1b subtype remained unchanged. However, there was no significant increase of At1 receptor protein in pancreatitis when compared with that in normal pancreas. The data indicate that the upregulation of At1 receptor, presumably via Atla subtype, but not At1b subtype may be responsible for the regulation of acute pancreatitis. For At2 receptor, it is more important to demonstrate that pancreatitis markedly and significantly increased the expression of At2 receptor in the pancreas ${ }^{9}$. Although the physiological role for At2 receptor in many tissues, especially in the pancreas remains unsettled, the role of At 2 receptor in the regulation of vascular injury ${ }^{15}$ and in the control of apoptosis has been recently addressed. Taking the data together, it is possible to speculate that the upregulation of At 2 receptor rather than At 1 receptor and activation of locally expressed angiotensinogen in the pancreas could have a more proeminent role in the regulation of physiology and possible pathophysiology of pancreatitis ${ }^{14}$.

Moreover, there was a selective upregulation of mRNAs for the At $1 \mathrm{~b}$ and At2 receptor subtypes by chronic hypoxia. Such differential changes of pancreatic RAS components may be responsible for finely regulating the physiology and adaptation of the pancreas during chronic hypoxia, but could also trigger hypoxia-induced pancreatic injury such as acute pancreatitis ${ }^{12}$. However, a recent study presented that the protective role At1 receptor antagonist, losartan, could be mediated by the inhibition of $\mathrm{NAD}(\mathrm{P}) \mathrm{H}$ oxidase-dependent generation of reactive oxygen species (ROS). Which can be related with antagonized effects of this drug on acute pancreatitis.

The role of RAS in the inflammatory process was further evidenced by the ability of an ACE inhibitor to suppress inflammation and subsequent tissue injury ${ }^{7}$. Some studies suggest that losartan, an At1 blocker, and lisinopril, an angiotensinconverting enzyme (ACE) inhibitor, can inhibit both the liver fibrosis and portal hypertension occurring in secondary biliary cirrhosis by inhibiting hepatic stellate cells (HSCs) activation ${ }^{10}$.

Stellate cells, previously known as Ito cells, vitamin A storing cells, or lipocytes ${ }^{2}$ are now know to play a major role in the production of hepatic fibrosis and are the major source of collagen and other extracellular matrix proteins in liver disease ${ }^{11}$. In the normal liver, stellate cells may be identified by the presence of fat droplets containing vitamin $\mathrm{A}^{10}$ and by positive staining for desmin, a cytoskeletal intermediate filament protein. The cells enlarge, proliferate, and lose the vitamin A - containing lipid droplets ${ }^{10}$. Activated stellate cells to recruitment the expression of extracellular matrix proteins, especially collagen types I and $\mathrm{III}^{2}$, is increased. Recent studies in the liver have established that stellate cells, when activated by profibrogenic mediators, play a key role in hepatic fibrogenesis by synthesizing and secreting increased amounts of extracellular matrix proteins ${ }^{13,10}$.

In the normal rat pancreas, stellate cells stain positively for desmin but do not stain for SMA, indicating a quiescent, nonactivated state ${ }^{5}$. Other studies in vitro of cultured pancreatic stellate cells have demonstrated that these cells exhibit morphological and functional features similar to cultured hepatic stellate cells, including positive SMA staining after a period of time in culture, increased proliferation in response to PDGF, and increased collagen synthesis in response to TGF $\beta^{6}$.

Other authors suggest that PSCs play an important role in pancreatic fibrogenesis and the cytokines PDGF and TGF $\beta$ may be involved in pancreatic fibrogenesis. A major source of TGF $\beta$ in the pancreas appears to be pancreatic acinar cells. It possible that TGF $\beta$ released by acinar cells secondary to cell injury may be one of the predominant factors promoting a fibrotic response in pancreatic stellate cells.

Dual staining techniques demonstrated colocalization of SMA staining (indicating activated stellate cells) and Sirius Red staining for collagen protein; this observation provides circumstantial evidence to support the concept that activated stellate cells may be involved in collagen production during pancreatic fibrogenesis. In the rat pancreas, Sirius Red collagen staining was closely associated with SMA-positive cells in serial sections. The relationship between pancreatic fibrosis and stellate cells was most clearly demonstrated in human pancreas by dual staining for collagen and $\mathrm{SMA}^{14}$.

Positive staining for the cytoskeletal protein desmin, a stellate cell marker, was found to be concentrated within areas of fibrosis in the pancreas, suggesting increased replication of stellate cells during fibrogenesis ${ }^{14}$ and a combination of immunostaining for SMA and in situ hybridization for procollagen mRNA demonstrated conclusively that it was activated stellate cells that were the principal source of collagen production in the fibrotic pancreas ${ }^{14}$.

Since PSC have some similarities to hepatic stellate cells and an intrinsic rennin-angiotensin system is present in the pancreas and is enhanced in acute pancreatitis and chronic pancreatic hypoxia, study showed the effects of lisinopril, on chronic pancreatitis. In another study, the same authors showed that candesartan, an angiotensin II receptor antagonist, improved the chronic inflammation and fibrosis on spontaneously occurring chronic pancreatitis in rats by suppressing the activation of pancreatic stellate cells ${ }^{14}$.

\section{Conclusion}

The pancreatic stellate cells strength are involved in collagen production during acute pancreatitis and possibly that these cells can become active through the action of angiotensin II produced by rennin-angiotensin.

\section{References}

1. Aho HJ, Nevalainen TJ, Havia VT, Heinonen RJ, Aho AJ. Human acute pancreatitis: a light and electron microscopic study. Acta Pathol Microbiol Immunol Scand. 1982;90:367-73.

2. Williams B, Baker AQ, Gallacher B, Lodwick D. Angiotensin II increases vascular permeability factor gene expression by human vascular smooth muscle cells. Hypertension. 1995;5:913-7. 
3. Ramalho LN, Ramalho FS, Zucoloto S, Castro-e-Silva Junior O, Correa FM, Elias Junior J, Magalhaes JF. Effect of losartan, an angiotensin II antagonist, on secondary biliary cirrhosis. Hepatogastroenterology. 2002;48:1499-502.

4. Tahmasebi M, Puddefoot JR, Inwang ER, Vinson GP. The tissue renin-angiotensin system in human pancreas. J Endocrinol. 1999;161:317-22. 5. Knoefel WT, Kollias N, Warshaw AL, Waldner H, Nishioka NS, Rattner DW. Pancreatic microcirculatory changes in experimental pancreatitis of graded severity in rat. Surgery. 1994;116:904-13.

6. Gressner AM, Bachem MG. Molecular mechanisms of liver fibrogenesis: a homage to the role of activated fat-storing cells. Digestion. 1995;56:335-46. 7. Pupilli C, Lasagni L, Romagnani P, Bellini F, Mannelli M, Misciglia N, Mavilia C, Vellei U, Villari D, Serio M. Angiotensin II stimulates the synthesis and secretion of vascular permeability factor/vascular endothelial growth factor in human mesangial cells. J Am Soc Nephrol. 1999;10:245-55. 8. Greestein RJ, Krako LR, Felton K. Activation of the renin system in acute pancreatitis. Am J Med. 1987;82:401-4.

9. Kyoko S. Mechanisms of pancreatic fibrosis and applications to the treatment of chronic pancreatitis. J Gastroenterol. 2008;43:823-32.

10. Agarwal N, Pitchumoni CS. Acute pancreatitis: a multisystem disease. Gastrenterologist. 1993;1:115-28.
11. Frossard JL, Pastor CM. Experimental acute pancreatitis: new insights into the pathophysiology. Front Biosci. 2002;7:275-87.

12. Hackenthal E, Paul M, Ganten D, Taugner R. Morphology, physiology, and molecular biology of rennin secretion. Physiol Rev. 1990;4:1067-116.

13. De Gasparo M, Catt KJ, Inagami T, Wright JW, Unger TH. The angiotensin II receptors. Pharmacol Rev. 2000;52:415-72.

14. Chan WP, Fung ML, Nobiling R, Leung PS. Activation of local renin - angiotensin system by chronic hypoxia. Molec Cell Endocrinol. 2000;160:107-14.

15. Ip SP, Kwan PC, Williams CH, Pang S, Hooper NM, Leung PS. Changes of angiotensin - converting enzyme activity in the pancreas of chronic hypoxia and acute pancreatitis. Int J Biochem Cell Biol. 2003;35:944-54.

\section{Acknowledgement}

The authors acknowledge in a special way to Auristella Martins for the invaluable technical assistance.

Conflict of interest: none Financial source: none

\section{Correspondence:}

Roberto de Barros Silva

Department of Pathology and Forensic Medicine

Ribeirão Preto Faculty of Medicine, University of Sao Paulo

Av. Bandeirante, 3900

14049-900 Ribeirão Preto - SP Brasil

robiomed@usp.br

Received: February 23, 2010

Review: April 20, 2010

Accepted: May 19, 2010

\section{How to cite this article}

Silva RB, Ramalho FS, Ramalho LZN. The effect of anti-hypertensive drugs on the obstructive pancreatitis in rats. Acta Cir Bras. [serial on the Internet] 2010 Sept-Oct;25(5). Available from URL: http://www.scielo.br/acb

*Color figures available from www.scielo.br/acb 